\title{
OPEN Tetraploid Citrumelo 4475 rootstocks improve diploid common clementine tolerance to long-term nutrient deficiency
}

Julie Oustric ${ }^{1 凶}$, Stéphane Herbette ${ }^{2}$, Yann Quilichini ${ }^{3}$, Raphaël Morillon ${ }^{4,5}$, Jean Giannettini ${ }^{1}$, Liliane Berti ${ }^{1} \&$ Jérémie Santini ${ }^{1}$

Nutrient deficiency alters growth and the production of high-quality nutritious food. In Citrus crops, rootstock technologies have become a key tool for enhancing tolerance to abiotic stress. The use of doubled diploid rootstocks can improve adaptation to lower nutrient inputs. This study investigated leaf structure and ultrastructure and physiological and biochemical parameters of diploid common clementine scions (C) grafted on diploid (2x) and doubled diploid (4x) Carrizo citrange (C/CC2x and $\mathrm{C} / \mathrm{CC} 4 \mathrm{x}$ ) and Citrumelo 4475 (C/CM2x and C/CM4x) rootstocks under optimal fertigation and after 7 months of nutrient deficiency. Rootstock ploidy level had no impact on structure but induced changes in the number and/or size of cells and some cell components of $2 x$ common clementine leaves under optimal nutrition. Rootstock ploidy level did not modify gas exchanges in Carrizo citrange but induced a reduction in the leaf net photosynthetic rate in Citrumelo 4475. By assessing foliar damage, changes in photosynthetic processes and malondialdehyde accumulation, we found that $\mathrm{C} / \mathrm{CM} 4 \mathrm{x}$ were less affected by nutrient deficiency than the other scion/rootstock combinations. Their greater tolerance to nutrient deficiency was probably due to the better performance of the enzyme-based antioxidant system. Nutrient deficiency had similar impacts on $\mathrm{C/CC2x}$ and C/CC4x. Tolerance to nutrient deficiency can therefore be improved by rootstock polyploidy but remains dependent on the rootstock genotype.

Fruit crops, especially citrus fruits, require large amounts of fertilizers to ensure good production and fruit quality. Today, the challenge for sustainable agriculture, and particularly organic agriculture, is to reduce the use of inputs in crops. Reducing inputs optimizes the economic outcome while limiting the environmental impact.

Water and minerals absorbed by roots in the soil are essential for plant development, growth and reproduction. Fourteen minerals are considered essential and these can be divided into two groups: the macroelements $(\mathrm{N}, \mathrm{K}, \mathrm{P}, \mathrm{Ca}, \mathrm{Mg}$ and $\mathrm{S}$ ) which are constituents of organic matter (proteins, nucleic acids) or play a strong osmotic role, and microelements $(\mathrm{Zn}, \mathrm{Cu}, \mathrm{Fe}, \mathrm{Mn}, \mathrm{B}, \mathrm{Mo}, \mathrm{Cl}$ and $\mathrm{Ni}$ ), which are only involved as specific cofactors or constituents of certain enzymes ${ }^{1-3}$. Mineral-deficient plants present various visual symptoms, such as necrosis, chlorosis, dark green foliage, or stunted growth ${ }^{4}$. Essential mineral deficiency alters plant primary metabolism and this disrupts the physiological and biochemical processes leading to changes in leaf structure and ultrastructure ${ }^{5,6}$. Moreover, cells must cope with an overproduction of reactive oxygen species (ROS) such as singlet oxygen $\left(\mathrm{O}^{*}\right)$, hydroxyl radicals $(\mathrm{OH})$, superoxide anion $\left(\mathrm{O}_{2}{ }^{-}\right)$and hydrogen peroxide $\left(\mathrm{H}_{2} \mathrm{O}_{2}\right)$ which cause membrane leakage due to lipid peroxidation and damage to proteins and nucleic acids ${ }^{7-9}$. As a result, ROS defence mechanisms are activated by a set of antioxidant compounds (metabolites such as ascorbate and proline) and antioxidant enzymes (superoxide dismutase (SOD), catalase (CAT), ascorbate peroxidase (APX) and dehydroascorbate reductase (DHAR)). Adapted genotypes are therefore sought in order to propose cultural itineraries more suitable to low input conditions.

${ }^{1}$ CNRS, Équipe de Biochimie et Biologie Moléculaire du Végétal, UMR 6134 SPE, Université de Corse, Corsica, France. ${ }^{2} \mathrm{UCA}$, INRAE, PIAF, Clermont-Ferrand, France. ${ }^{3} \mathrm{CNRS}$, Équipe des Parasites et Ecosystèmes Méditerranéens, UMR 6134 SPE, Université de Corse, Corsica, France. ${ }^{4}$ Equipe SEAPAG, CIRAD, UMR AGAP, Petit-Bourg, 97170 Guadeloupe, France. ${ }^{5}$ AGAP, CIRAD, INRAE, Institut Agro, Univ Montpellier, Montpellier, France. ${ }^{\square}$ email: oustric_j@univ-corse.fr 
In citrus crops, improving the performance of varieties is based on the scion/rootstock combination forming the aerial parts and roots of the plant, respectively. The impact of the rootstock on the scion lies in its influence on the plant growth and development and the adaptation to environmental conditions ${ }^{10}$. Grafting improves the agronomic fruit quality by increasing synthesis of endogenous hormones and the acquisition and transport of mineral nutrient ${ }^{11,12}$. It also influences the organoleptic quality by impairing secondary metabolites which impacts the flavour ${ }^{11,13}$ and the content of fruit metabolites ${ }^{14,15}$. An efficient translocation of water and mineral nutrients between rootstock and scion promote biomass production and tolerance to biotic and abiotic factors, such as nutrient deficiency ${ }^{16,17}$. Improved root system vigour in citrus rootstocks results in increased soil nutrient and water uptake ${ }^{15,18}$. All modern cultivated varieties of citrus are now grafted on diploid rootstocks and therefore have two sets of chromosomes in their genetic heritage. However, incomplete mitosis of somatic embryos may occur in seedlings of diploid (2x) apomictic genotypes with formation of doubled diploid (4x) genotypes ${ }^{19}$.

Tetraploidy modifies phenotypic characteristics such as size and density of stomata, root and leaf morphology as well as growth, development and quality of fruits ${ }^{20}$. These changes may result in an upheaval in physiological processe $^{21}$. Studies have shown that tetraploid citrus rootstocks can lead to a reduction in yield without changing the quality of the fruit ${ }^{22-24}$. Recent advances have shown an interesting impact of the rootstock tetraploidy on the scion tolerance to environmental stresses. For example, grafting of Valencia Delta sweet orange (Citrus sinensis L.) on $4 \mathrm{x}$ rangpur lime (Citrus limonia) rootstock was found to improve its tolerance to water stress by changing patterns of gene expression in Rangpur lime citrus roots regulating adaptation to water deficit ${ }^{25}$. Natural chilling stress tolerance associated with a robust antioxidant system was also enhanced in $2 x$ common clementine (Citrus clementina Hort. ex Tan) grafted with Carrizo citrange (Citrus sinensis Osb. $\times$ Poncirus trifoliata L. Raf.) $4 \mathrm{x}$ rootstock ${ }^{26}$. Chromium tolerance of Kinnow mandarin (Citrus nobilis Lour x Citrus deliciosa Ten) grafted on three $4 \mathrm{x}$ rootstocks (Poncirus trifoliata [L.], Citrus reshni, and Citrus limonia Osbeck.) may be attributed to chromium sequestration in roots with lower transfer to leaves in $4 \mathrm{x}$ rootstocks ${ }^{27}$. The use of rootstocks better adapted to environmental constraints seems to be a promising eco-friendly strategy.

Many Citrus genotypes are used as rootstock for citrus cultivation. Genotypes belong either to the Citrus genus such as Volkamer lemon or are obtained by hybridization between Citrus and Poncirus genus progenitors such as Citrumelo 4475 and Carrizo citrange. Volkamer lemon which is used as rootstock for lemon, is adapted to dry, calcareous and saline soils and presents tolerance to Tristeza, cachexia and exocortis. Citrumelo 4475 imparts cold tolerance to the scion. Carrizo citrange is frequently used in acidic and neutral soils but not in dry areas because of its limited performance under drought conditions. These two genotypes inherited Tristeza tolerance from their Trifoliate orange progenitor and give clementine varieties that produce a high yield and fruit quality ${ }^{28}$.

In a previous study, we compared leaf structure and ultrastructure under nutrient deficiency of two genotypes used worldwide as rootstock for citrus cultivation, the Citrumelo 4475 (Citrus paradisi L. Macf. $\times$ Poncirus trifoliata L. Raf.) and Volkamer lemon (Citrus limonia Osb.) with both $2 \mathrm{x}$ and $4 \mathrm{x}$ genotypes ${ }^{29}$. Results showed an increase in tolerance to nutrient deficiency in $4 \mathrm{x}$ genotypes. Doubled diploid genotypes presented less degradation of ultrastructural components such as chloroplasts, thylakoids, mitochondria and starch grains associated with a smaller decrease in leaf net photosynthetic rate $\left(P_{\text {net }}\right)$, stomatal conductance $\left(g_{\mathrm{s}}\right)$ and chlorophyll fluorescence $\left(F_{\mathrm{v}} / F_{\mathrm{m}}\right)$ compared to $2 \mathrm{x}$ genotypes.

The higher tolerance to nutrient deficiency was linked to the reduced accumulation of malondialdehyde (MDA) and $\mathrm{H}_{2} \mathrm{O}_{2}$ in Citrumelo $44754 \mathrm{x}$ than in the $2 \mathrm{x}$, implying a more efficient antioxidant system in the $4 \mathrm{x}$ genotype. However, few differences in the antioxidant system and oxidative status were observed between $2 \mathrm{x}$ and $4 \mathrm{x}$ Volkamer lemons.

The aim of this study was therefore to determine the impact of three combined factors, (i) the rootstock genotypes (ii), the rootstock ploidy level and (iii) the nutrient deficiency on the $2 x$ common clementine scion. We selected $2 \mathrm{x}$ common clementine grafted on two rootstocks used worldwide for clementine cultivation, i.e. Citrumelo 4475 (C/CM2x) and Carrizo citrange (C/CC2x) in both 2x and 4x types (C/CM4x and C/CC4x, respectively). The effect of rootstock ploidy level on $2 \mathrm{x}$ common clementine scions under nutrient deficiency was investigated by studying $2 x$ common clementine leaf structure and ultrastructure and physiological and biochemical parameters.

\section{Results and discussion}

Effect of rootstock ploidy level on anatomical properties of $2 \mathrm{x}$ common clementines under control conditions.

All the scion/rootstock combinations present similar leaves colour, $\mathrm{N}$ contents and chlorophyll contents (Figs. 1, 2D, Table 1).

It is understandable as $\mathrm{N}$ is a structural element of chlorophyll and thereby affects leaf colour ${ }^{30-32}$. P and $\mathrm{Na}$ contents were also similar between all scion/rootstock combinations while $\mathrm{K}$ and $\mathrm{Ca}$ contents were lower in $\mathrm{C} /$ $\mathrm{CM} 2 \mathrm{x}$ and $\mathrm{C} / \mathrm{CC} 4 \mathrm{x}$ compared to the other scion/rootstock combination. Considering the Mg content, it was different between the 2x common clementine grafted onto Citrumelo 4475 and Carrizo citrange and between ploidy level for Citrumelo 4475. These results suggest that the rootstock genotypes and their ploidy level can influence the nutrient minerals content in the scion leaves.

Whatever the rootstock genotype and ploidy level, microscopic examination of leaf surface imprints confirmed the presence of stomata only on their abaxial surface that were surrounded by ordinary epidermal cells ${ }^{33}$ (anomocytic organization) (Fig. 1). Rootstock tetraploidy did not induce any changes in the location of stomata or the epidermal cell structure of $2 x$ common clementine leaves. This agrees with this anomocytic organization observed on leaves of tetraploid seedlings ${ }^{29}$.

Stomata size was unchanged in 2x common clementine scion regardless of the rootstocks ploidy level but was higher with Citrumelo 4475 than Carrizo citrange rootstock (Fig. 3, Table 2, Supplementary Table S1). Rootstock genotype influence the stomata density of the $2 \mathrm{x}$ common clementine scion but not the ostiole size. 


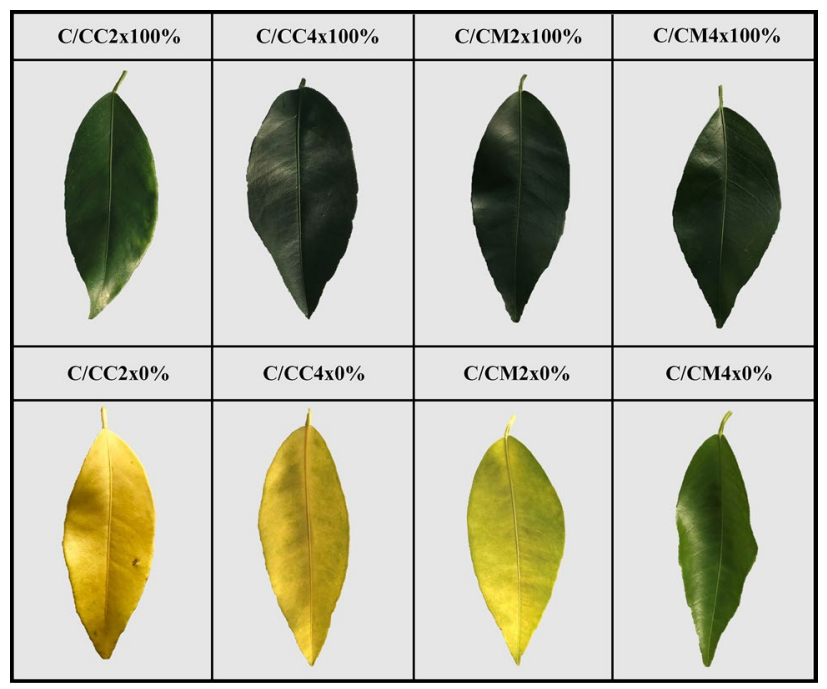

Figure 1. Leaf damages of common clementine scion grafted onto different rootstocks. Leaf damages of common clementine scion grafted onto diploid (C/CC2x) and doubled diploid (C/CC4x) Carrizo citrange and diploid (C/CM2x) and doubled diploid (C/CM4x) Citrumelo 4475 rootstocks grown in nutrient reference solution $(100 \%)$ and without nutrient solution $(0 \%)$.

Stomata density and ostiole size was influenced by the rootstock ploidy level in Carrizo citrange with respectively a decrease and increase in C/CC4x compared to C/CC2x combinations (Fig. 3, Table 2, Supplementary Table S1).

Studies have shown a positive correlation between stomata and ostiole size and a negative correlation between stomata density and ploidy level in both $4 \mathrm{x}$ ungrafted genotypes and $3 x$ clementine in comparison to their $2 \mathrm{x}$ counterparts ${ }^{29,33,34}$. Our study showed that $4 \mathrm{x}$ rootstocks had no effect on stomata sizes in $2 \mathrm{x}$ common clementine scions and a non-systematic impact on ostiole size and stomatal density, putatively through changes in hydraulics or mineral inputs. The decrease in stomatal density caused by rootstock tetraploidy in the C/CC4x combination was not associated with any changes in gas exchanges compared to its C/CC2x counterpart (Figs. 2, 3, Table 2, Supplementary Table S1). The increase in ostiole size in the C/CC4x combination compared to its C/ CC2x counterpart suggests an adjustment of the stomata opening to compensate for the reduced stomatal density and maintain stomatal conductance ${ }^{35}$. This adjustment could be due to the considerable degradation of starch grains in the guard cells in the first hour of light contributing to a rapid increase in the opening of the stomata in parallel with the activation of membrane ion transport ${ }^{36,37}$.

Despite identical physical stomatal attributes between C/CM2x and C/CM4x combinations, analysis of the gas exchange parameters revealed a decrease of $P_{\text {net }}$ in the C/CM4x combination (Figs. 2, 3, Table 2, Supplementary Table S1). Other factors than leaf structure therefore appear to be involved in the regulation of photosynthesis in the C/CM4x combination.

At ultrastructural level, genotypes and ploidy level influence the cell size and thickness in palisade and mesophylls as indicated by their reduction in C/CC4x compared to C/CC2x, and their increase in C/CM4x compared to C/CM2x (Figs. 4, 5, Tables 3, 4, Supplementary Tables S2, S3).

These ultrastructural modifications were the only identical changes in C/CM4x and the ungrafted rootstock counterpart ${ }^{29}$. In contrast to its ungrafted counterpart, C/CM4x showed a lower $P_{\text {net }}$ and similar chloroplast numbers to C/CM2 ${ }^{29}$ (Figs. 2A, 4, 5, Tables 3, 4, Supplementary Tables S2, S3). Chloroplast enlargement in palisade mesophyll brought about by rootstock tetraploidy in 2x common clementine leaves was not associated with an increase in chloroplast numbers. This phenomenon appears to reduce photosynthetic capacity ${ }^{38}$. Overall, under optimal conditions and depending on the rootstock genotypes, the structural and/or ultrastructural modifications of the $2 x$ common clementine leaves induced by rootstock tetraploidy could either compensate each other with no change in gas exchanges or induce a modification of gas exchanges. On the whole, the number and size of transitory starch grains and mitochondria in palisade and spongy mesophylls in $2 x$ common clementine scion were either reduced or similar between $2 \mathrm{x}$ and $4 \mathrm{x}$ rootstock of all the scion rootstock combination (Figs. 4, 5, Tables 3, 4, Supplementary Tables S2, S3). The number of plastoglobuli increased in C/CM4x and C/ CC4x compared to C/CM2x and C/CC2x in the chloroplasts of the palisade and spongy mesophylls. Only the C/ CM4x plastoglobuli were larger than those of its 2x counterpart (Figs. 4, 5, Tables 3, 4, Supplementary Tables S2, S3). Thus, rootstock tetraploidy involved a potential increase in lipid (plastoquinone-9 (PQ-9), plastoquinol-9 (PQ-9H2) and a-tocopherol (a-T)) reserves that could not be deposited in the thylakoids of chloroplasts. Genotype and/or ploidy level of the rootstocks may influence the mineral content, structure and ultrastructure of 2x common clementine leaves.

Differences in photosynthetic properties and redox status of scion/rootstock combinations under nutrient stress could be related to their leaf and cell anatomy.

Complete starvation resulted in a significant decrease in $\mathrm{N}$ but similar or higher levels of $\mathrm{P}, \mathrm{K}, \mathrm{Mg}, \mathrm{Ca}$ and $\mathrm{Na}$ than controls in all scion/rootstock combinations (Table 1). A concentration effect induced by the transfer of 


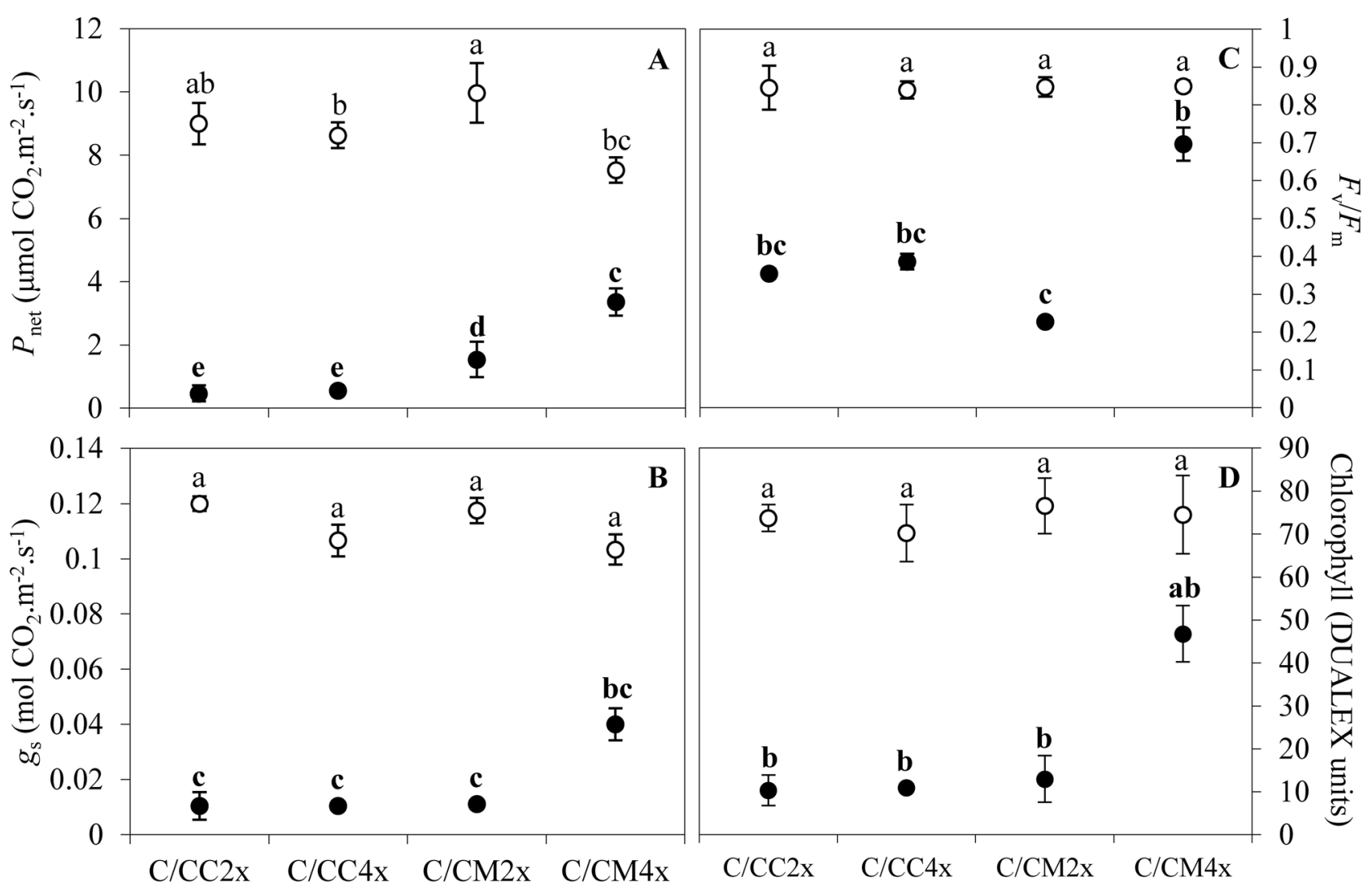

Figure 2. Effect of nutrient deficiency on photosynthetic properties of leaves of common clementine scion grafted onto different rootstocks. (A) Leaf net photosynthetic rate $\left(P_{\text {net }}\right),(\mathbf{B})$ stomatal conductance $\left(g_{\mathrm{s}}\right),(\mathbf{C})$ chlorophyll fluorescence $\left(F_{\mathrm{v}} / F_{\mathrm{m}}\right)$ and $(\mathbf{D})$ chlorophyll contents of leaves of common clementine scion grafted onto diploid (C/CC2x) and doubled diploid (C/CC4x) Carrizo citrange and diploid (C/CM2x) and doubled diploid (C/CM4x) Citrumelo 4475 rootstocks grown in nutrient reference solution (100\%) (white circles) and without nutrient solution ( $0 \%$ ) (black circles) for 210 days. Values are mean ( \pm standard error) of 9 independent measurements $(n=9)$ for each scion/rootstock combination, i.e. three per tree. Ploidy and treatment effects were analyzed using ANOVA and Fisher LSD tests $(p<0.05)$. Distinct letters indicate significant differences between all scion/rootstocks combinations and treatments.

\begin{tabular}{|c|c|c|c|c|c|c|c|c|}
\hline \multirow[b]{2}{*}{ Nutrients } & \multicolumn{2}{|l|}{$\mathrm{C} / \mathrm{CC} 2 \mathrm{x}$} & \multicolumn{2}{|l|}{$\mathrm{C} / \mathrm{CC} 4 \mathrm{x}$} & \multicolumn{2}{|l|}{ C/CM2x } & \multicolumn{2}{|l|}{$\mathrm{C} / \mathrm{CM} 4 \mathrm{x}$} \\
\hline & $100 \%$ & $0 \%$ & $100 \%$ & $0 \%$ & $100 \%$ & $0 \%$ & $100 \%$ & 0\% \\
\hline $\mathrm{N}(\%)$ & $2.98 \pm 0.15^{\mathrm{a}}$ & $1.12 \pm 0.06^{\mathrm{b}}$ & $3.39 \pm 0.44^{\mathrm{a}}$ & $1.19 \pm 0.05^{\mathrm{b}}$ & $3.32 \pm 0.04^{\mathrm{a}}$ & $1.15 \pm 0.05^{\mathrm{b}}$ & $3.90 \pm 0.57^{\mathrm{a}}$ & $1.28 \pm 0.03^{\mathrm{b}}$ \\
\hline $\mathrm{P}(\%)$ & $0.15 \pm 0.01^{b}$ & $0.43 \pm 0.02^{\mathrm{a}}$ & $0.18 \pm 0.01^{b}$ & $0.38 \pm 0.02^{\mathrm{a}}$ & $0.15 \pm 0.00^{\mathrm{b}}$ & $0.16 \pm 0.01^{\mathrm{b}}$ & $0.14 \pm 0.00^{\mathrm{b}}$ & $0.20 \pm 0.01^{\mathrm{b}}$ \\
\hline K (\%) & $2.60 \pm 0.15^{\mathrm{b}}$ & $4.85 \pm 0.10^{\mathrm{a}}$ & $2.21 \pm 0.00^{b}$ & $4.13 \pm 0.04^{\mathrm{a}}$ & $1.79 \pm 0.08^{c}$ & $2.79 \pm 0.26^{b}$ & $2.34 \pm 0.22^{b}$ & $2.33 \pm 0.10^{b}$ \\
\hline $\mathrm{Ca}(\%)$ & $1.61 \pm 0.19^{\mathrm{ab}}$ & $1.85 \pm 0.15^{\mathrm{a}}$ & $1.32 \pm 0.15^{\mathrm{c}}$ & $1.42 \pm 0.08^{\mathrm{bc}}$ & $1.67 \pm 0.30^{\mathrm{ab}}$ & $1.63 \pm 0.11^{\mathrm{ab}}$ & $1.65 \pm 0.21^{\mathrm{ab}}$ & $1.58 \pm 0.10^{\mathrm{b}}$ \\
\hline $\mathrm{Mg}(\%)$ & $0.61 \pm 0.02^{\mathrm{cd}}$ & $0.89 \pm 0.04^{\mathrm{ab}}$ & $0.69 \pm 0.07^{\mathrm{c}}$ & $0.80 \pm 0.01^{b}$ & $0.54 \pm 0.03^{\mathrm{d}}$ & $0.68 \pm 0.06^{c}$ & $0.87 \pm 0.02^{\mathrm{ab}}$ & $0.96 \pm 0.08^{\mathrm{a}}$ \\
\hline $\mathrm{Na}(\%)$ & $0.016 \pm 0.001^{\mathrm{b}}$ & $0.040 \pm 0.002^{\mathrm{ab}}$ & $0.014 \pm 0.000^{\mathrm{b}}$ & $0.063 \pm 0.004^{\mathrm{a}}$ & $0.014 \pm 0.001^{\mathrm{b}}$ & $0.019 \pm 0.000^{b}$ & $0.018 \pm 0.001^{b}$ & $0.018 \pm 0.000^{\mathrm{b}}$ \\
\hline
\end{tabular}

Table 1. Total content of macronutrient in leaves of common clementine scion grafted onto different rootstocks. Nitrogen $(\mathrm{N})$, phosphorus $(\mathrm{P})$, potassium $(\mathrm{K})$, magnesium $(\mathrm{Mg})$, calcium $(\mathrm{Ca})$ and sodium $(\mathrm{Na})$ content in leaves of common clementine scion grafted onto diploid (C/CC2x) and doubled diploid (C/CC4x) Carrizo citrange and diploid (C/CM2x) and doubled diploid (C/CM4x) Citrumelo 4475 rootstocks grown in nutrient reference solution $(100 \%)$ and without nutrient solution $(0 \%)$. Values are means $( \pm$ standard error) of 3 independent measurements from 3 samples for each scion/rootstock, i.e. one per tree $(n=3)$. One sample was obtained by pooling 8 fully-expanded leaves. Data were analyzed using ANOVA and Fisher LSD tests $(p<0.05)$. Different letters indicate significant differences between the four scion/rootstock combinations and treatments.

$\mathrm{N}$ to other tree areas could explain the increase in $\mathrm{P}, \mathrm{K}$ and $\mathrm{Mg}$ contents in all scion/rootstock combinations ${ }^{39}$. Leaf chlorosis occurs when plants do not have the nutrients needed for chlorophyll synthesis, which in turn affects the photosynthetic efficiency ${ }^{40}$. However, the decrease in $\mathrm{N}$, which was an important factor in chlorosis, 

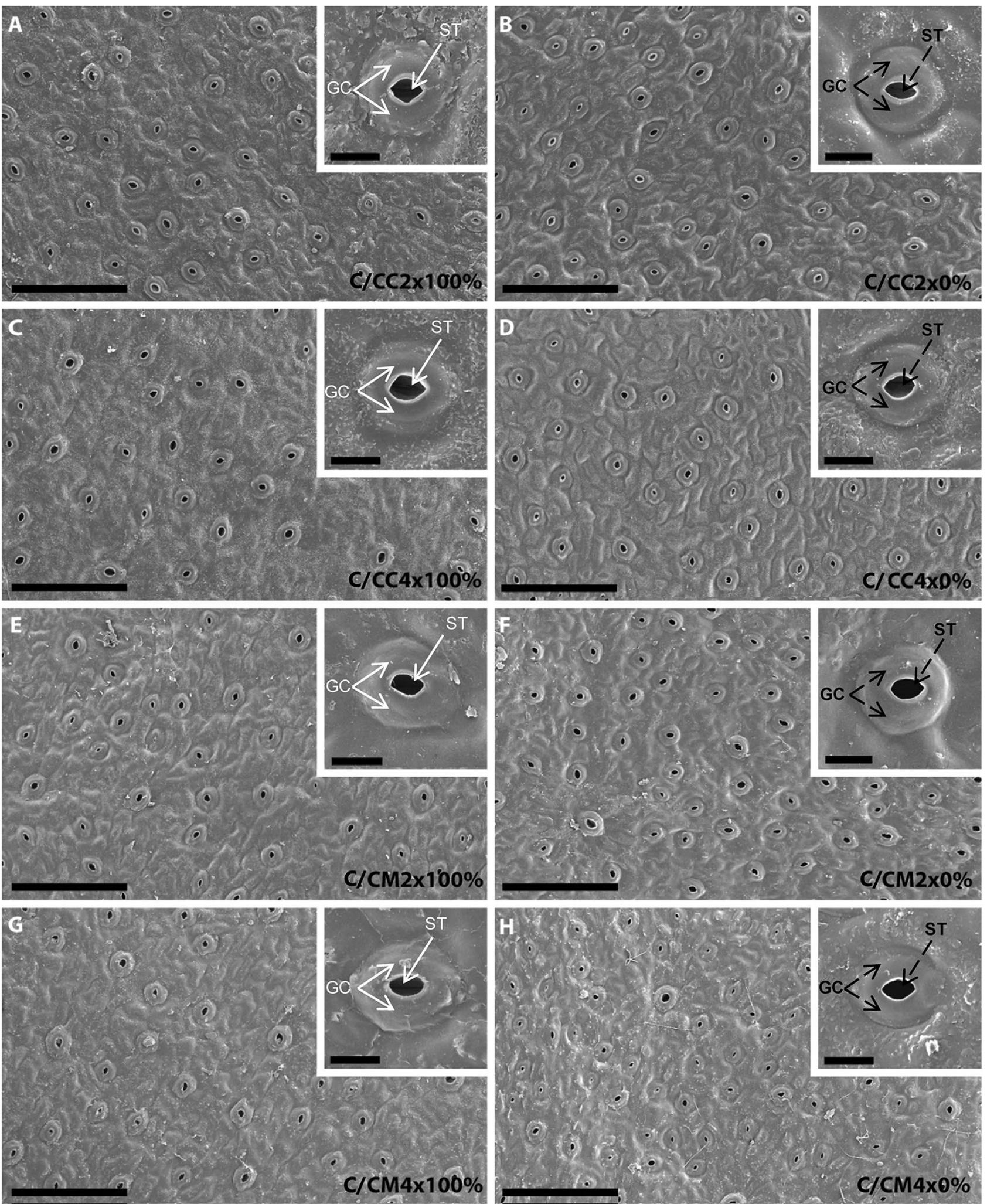

Figure 3. Scanning electron micrographs of abaxial epidermis and stomata in leaves of common clementine scion grafted onto different rootstocks. Abaxial epidermis and stomata of leaves of common clementine scion grafted onto diploid (C/CC2x) and doubled diploid (C/CC4x) Carrizo citrange and diploid (C/CM2x) and doubled diploid (C/CM4x) Citrumelo 4475 rootstocks grown in nutrient reference solution $(100 \%)(\mathbf{A}, \mathbf{C}, \mathbf{E}, \mathbf{G})$ and without nutrient solution $(0 \%)(\mathbf{B}, \mathbf{D}, \mathbf{F}, \mathbf{H})$ for 210 days. Scale bars $(10 \mu \mathrm{m})$ are indicated at the bottom left for each image. The significant values between rootstock ploidy level of scion/rootstock combinations and treatment are shown in black and bold with a black dotted arrow. ST ostiole (stoma), GC guard cells. 


Color Key
and Density Plot

Table 2. Anatomy of the leaf epidermis of common clementine scion grafted onto different rootstock. Anatomical characters of leaves epidermis of common clementine scion grafted onto diploid (C/CC2x) and doubled diploid (C/CC4x) Carrizo citrange and diploid (C/CM2x) and doubled diploid (C/CM4x) Citrumelo 4475 rootstocks grown in nutrient reference solution (100\%) and without nutrient solution ( $0 \%)$ for 210 days. For length and width of stomata and ostioles, values are means ( \pm standard error) of 30 independent measurements on three different leaves $(n=90)$. For stomatal density, values are means of five independent measurements on three different leaves $(n=15)$ for stomatal density. The heatmap shows the differences between the four scion/rootstocks combinations and treatments for each characteristic. Values are associated with color ranging from yellow (low) to dark green (high).

was similar in all scion/rootstock combinations (Table 1). C/CM4x showed less chlorosis as indicated by its light green colour compared with the yellow colour of other scion/rootstock combinations (Fig. 1). Less pronounced chlorosis in $\mathrm{C} / \mathrm{CM} 4 \mathrm{x}$ is correlated with a slight decrease in chlorophyll content than in other the scion/rootstock combinations (Figs. 1, 2D).

These results suggest that, depending on the rootstock genotype, the tetraploidy may provide a better integrity of chlorophyll content probably related to a better protection against ROS in $2 \mathrm{x}$ common clementine scion under nutrient deficiency ${ }^{41-43}$. The improvements in the redox status of scions by tetraploid rootstocks is probably linked to an improvement in photosynthesis.

Chlorosis was associated with structural and ultrastructural foliar changes and a disruption of photosynthetic properties in all scion/rootstock combinations ${ }^{6,44}$ (Figs. 1, 2, 3, 4, 5, Tables 2, 3, 4, Supplementary Tables S1-S3). At structural level, stomata and ostioles of all scion/rootstock combinations showed a narrowing which was associated with an increase in density (except in C/CC2x) response to nutrient deficiency (Fig. 3, Table 2, Supplementary Table S1). The rootstock apparently has a different effect on the structural components of 2x common clementine leaves depending on genotype and/or ploidy level. $P_{\text {net }}$ and $g_{\mathrm{s}}$ decreased concomitantly in all scion/ rootstock combinations under nutrient deficiency (Fig. 2A,B). These results suggest a critical role of stomatal structure in the process of $\mathrm{CO}_{2}$ availability ${ }^{45}$. However, the smaller decrease in $P_{\text {net }}, g_{\mathrm{s}}$ and $F_{\mathrm{v}} / F_{\mathrm{m}}$ in C/CM4x than in other scion/rootstock combinations (Fig. 2A-C) implies that other factors than stomata are needed to sustain photosynthesis ${ }^{46-48}$.

At ultrastructural level, nutrient deficiency resulted in slight cell size enlargement in palisade mesophyll, thylakoid with grana degradation and a decrease in chloroplast size in leaf mesophylls of all scion/rootstock combinations (Figs. 4, 5, Tables 3, 4, Supplementary Tables S2, S3). Similar results were recorded in other plants under conditions of high light stress, infection, dark-induced senescence or total nutrient deficiency ${ }^{6,29,49,50}$. Chloroplast degradation may be due to the significant decrease in $\mathrm{N}$ in the mature leaves of each scion/rootstock combination following the extensive remobilization of $\mathrm{N}$ present in the cell to younger leaves or storage areas during nutrient deficiency ${ }^{51,52}$ (Figs. 4, 5, Tables 1, 3, 4, Supplementary Tables S2, S3).

The overproduction of reactive oxygen species (ROS) leads to alterations in the integrity of the membrane structures of cells, chloroplasts or thylakoids by a process called lipid peroxidation, one of the indicators of which is malondialdehyde (MDA). The lower MDA content in C/CM4x compared to other scion/rootstock combinations was consistent with the reduced damage to ultrastructure (Figs. 4, 5, 6D, Tables 3, 4, Supplementary Tables S2, S3). Thylakoid size and structure is dependent on the formation of PSII-LHCII supercomplexes ${ }^{53}$. In $\mathrm{C} / \mathrm{CM} 4 \mathrm{x}$, the lower decrease in $F_{\mathrm{v}} / F_{\mathrm{m}}$ suggests that $\mathrm{N}$ decrease leads a more limited degradation of the PSIILHCII supercomplexes reducing the disruption of electron transport for the photosynthetic reaction and thus the production of ROS in comparison to the other scion/rootstock combination ${ }^{9,54,55}$ (Figs. 2C, 6D). Maintaining the redox balance in $\mathrm{C} / \mathrm{CM} 4 \mathrm{x}$ decelerates the degradation of $\mathrm{N}$ pool of the chlorophyll and thereby thylakoids that result in a more efficient photosynthetic capacity $\left(P_{\text {net }}\right.$ and $\left.F_{\mathrm{v}} / F_{\mathrm{m}}\right)$ (Figs. 2A,C,D, 4, 5, Tables 3, 4, Supplementary Table S2, S3). In addition, a lower allocation of $\mathrm{N}$ for Rubisco in support of membrane formation would explain the maintenance of chloroplast size and less advanced thylacoid degradation in C/CM4x. This phenomenon is 

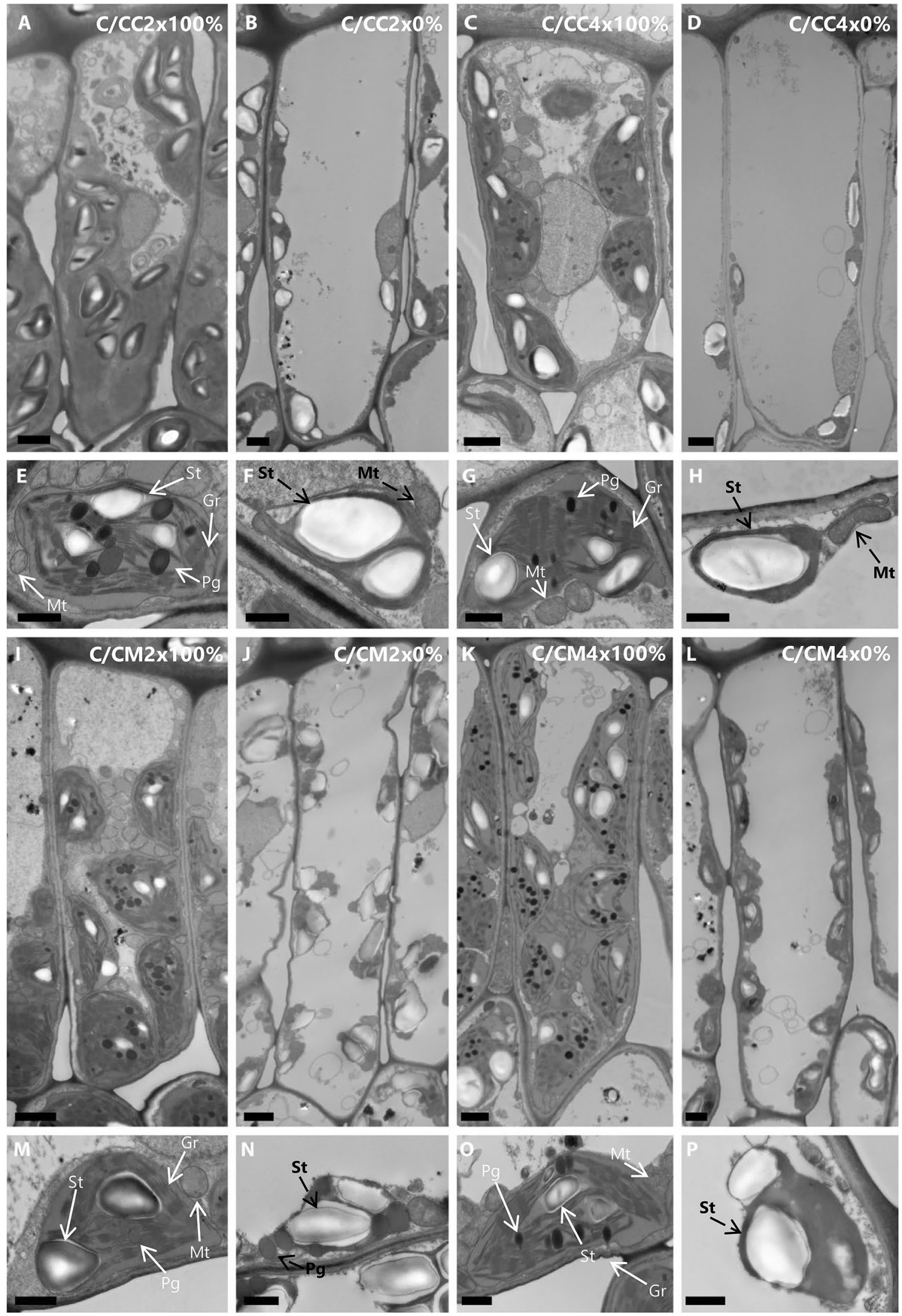

Figure 4. Transmission electron micrographs of palisade mesophyll cells in leaves of common clementine scion grafted onto different rootstocks. ((A,B,C,D,I,J,K,L); scale bar: $5 \mu \mathrm{m})$ Palisade mesophyll cells and ((E,F,G,H,M,N,O,P); scale bar: $1 \mu \mathrm{m})$ their respective chloroplasts in leaves of common clementine scion grafted onto diploid (C/CC2x) and doubled diploid (C/CC4x) Carrizo citrange and diploid (C/CM2x) and doubled diploid (C/CM4x) Citrumelo 4475 rootstocks grown in nutrient reference solution (100\%). Scale bars for palisade mesophyll cells $(5 \mu \mathrm{m})$ and their respective chloroplasts in leaves $(1 \mu \mathrm{m})$ are indicated at the bottom left for each image. The significant values between rootstock ploidy level of scion/rootstock combinations and treatment are shown in bold and black with a black dotted arrow. St starch, Pg plastoglobuli, $M t$ mitochondria, Gr granum. 

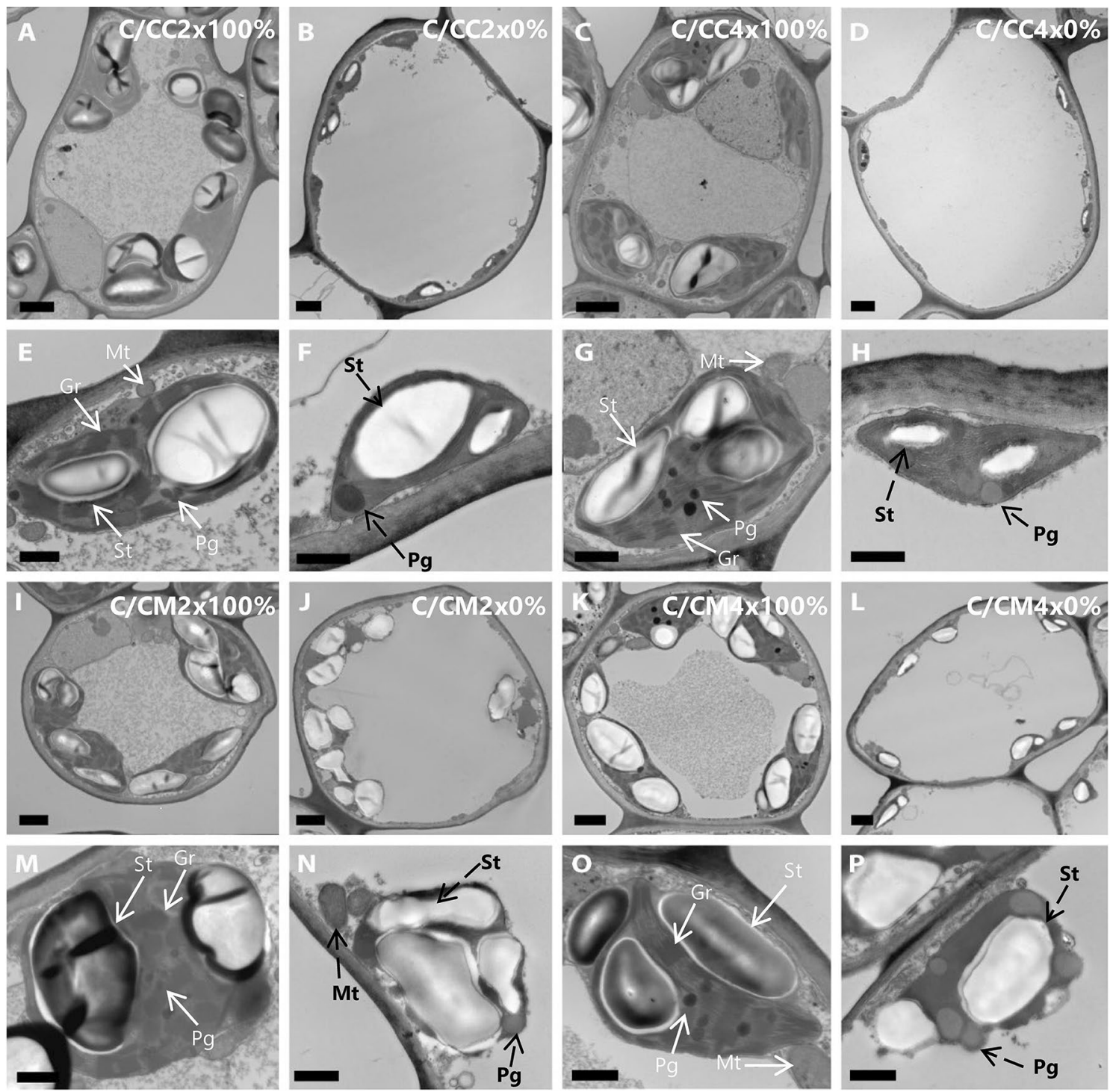

Figure 5. Transmission electron micrographs of spongy mesophyll cells of leaves of common clementine scion grafted onto different rootstocks. ((A,B,C,D,I,J,K,L); scale bar: $5 \mu \mathrm{m})$ Spongy mesophyll cells and $((\mathbf{E}, \mathbf{F}, \mathbf{G}, \mathbf{H}, \mathbf{M}, \mathbf{N}, \mathbf{O}, \mathbf{P})$; scale bar: $1 \mu \mathrm{m})$ their respective chloroplasts in leaves of common clementine scion grafted onto diploid (C/CC2x) and doubled diploid (C/CC4x) Carrizo citrange and diploid (C/CM2x) and doubled diploid (C/CM4x) Citrumelo 4475 rootstocks grown in nutrient reference solution (100\%). Scale bars for spongy mesophyll cells $(5 \mu \mathrm{m})$ and their respective chloroplasts in leaves $(1 \mu \mathrm{m})$ are indicated at the bottom left for each image. The significant values between rootstock ploidy level of scion/rootstock combinations and treatment are shown in bold and black with a black dotted arrow. St starch, $P g$ plastoglobuli, $M t$ mitochondria, Gr granum.

consistent with the higher chlorophyll content in C/CM4x which would explain its more efficient regulation of photosynthesis $^{30}$.

Plastoglobuli are bound to thylakoids via their membranes. Studies have shown that plastoglobuli are involved in the formation and degradation of thylakoids during plant growth, development and senescence but also when plants are exposed to drought, high-light, $\mathrm{N}$ starvation or fungal infection ${ }^{50,56-58}$. The reduced damage of the thylakoid membrane in C/CM4x would explain the smallest change or maintenance of the plastoglobuli numbers associated to a small increase in their size under $\mathrm{N}$ decrease due to the accumulation of catabolites formed by thylakoid degradation in their hydrophobic core compared to other scion/rootstock combinations ${ }^{59-62}$ (Figs. 4, 5, Tables 1, 3, 4, Supplementary Table S2, S3).

Tetraploidy of the Citrumelo 4475 rootstock improves the tolerance of $2 x$ common clementine scions by maintaining the redox status and delaying ultrastructural changes and damage with a consequent improvement in photosynthetic capacity. However, as suggested by the similar impact of nutrient deficiency on C/CC2x and $\mathrm{C} / \mathrm{CC} 4 \mathrm{x}$, the rootstock tetraploidy depending on their genotypes does not automatically result in better tolerance of the photosynthetic properties of the scion. 


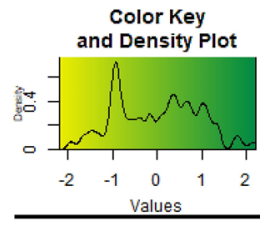

$\mathrm{C} / \mathrm{CC} 2 \mathrm{x}$

$\mathrm{C} / \mathrm{CC4x}$

C/CM2X

C/CM4x

Characters

Palisade mesophyll cells

\begin{tabular}{|c|c|c|c|c|c|c|c|c|c|}
\hline & & $100 \%$ & $0 \%$ & $100 \%$ & $0 \%$ & $100 \%$ & $0 \%$ & $100 \%$ & $0 \%$ \\
\hline \multirow{3}{*}{ Cells } & Length $(\mu \mathrm{m})$ & 27.414 & 30.242 & 20.684 & 32.802 & 25.402 & 32.472 & 30.827 & 34.334 \\
\hline & Width $(\mu \mathrm{m})$ & 8.375 & 10.593 & 7.307 & 9.498 & 6.933 & 6.600 & 9.010 & 10.082 \\
\hline & Thickness $(\mu \mathrm{m})$ & 0.399 & 0.393 & 0.298 & 0.570 & 0.350 & 0.344 & 0.432 & 0.426 \\
\hline \multirow{3}{*}{ Chloroplasts } & Number & 7.400 & 4.400 & 5.600 & 3.000 & 6.000 & 6.400 & 6.600 & 9.600 \\
\hline & Length $(\mu \mathrm{m})$ & 5.658 & 4.203 & 4.493 & 4.049 & 5.014 & 4.923 & 7.135 & 6.669 \\
\hline & Width $(\mu \mathrm{m})$ & 2.665 & 1.776 & 2.659 & 1.798 & 2.989 & 2.776 & 3.600 & 2.856 \\
\hline \multirow{3}{*}{ Starches } & Number & 11.800 & 7.400 & 12.000 & 3.600 & 15.600 & 14.400 & 12.200 & 13.000 \\
\hline & Length $(\mu \mathrm{m})$ & 1.032 & 1.933 & 1.590 & 2.783 & 2.320 & 2.616 & 1.324 & 1.979 \\
\hline & Width $(\mu \mathrm{m})$ & 0.724 & 1.065 & 0.958 & 1.064 & 1.328 & 1.644 & 0.925 & 1.196 \\
\hline \multirow{3}{*}{ Plastoglobuli } & Number & 31.666 & 12.400 & 39.600 & 4.800 & 17.000 & 38.600 & 55.200 & 39.600 \\
\hline & Length $(\mu \mathrm{m})$ & 0.396 & 0.549 & 0.311 & 0.892 & 0.328 & 0.628 & 0.465 & 0.595 \\
\hline & Width $(\mu \mathrm{m})$ & 0.314 & 0.517 & 0.226 & 0.592 & 0.285 & 0.445 & 0.306 & 0.374 \\
\hline \multirow{3}{*}{ Mitochondria } & Number & 19.000 & 7.400 & 13.600 & 4.800 & 18.000 & 8.000 & 18.800 & 15.400 \\
\hline & Length $(\mu \mathrm{m})$ & 0.841 & 0.762 & 0.753 & 0.740 & 0.934 & 0.605 & 0.890 & 0.980 \\
\hline & Width $(\mu \mathrm{m})$ & 0.657 & 0.568 & 0.575 & 0.506 & 0.676 & 0.461 & 0.592 & 0.625 \\
\hline \multirow{3}{*}{ Grana } & Number of grana per cell & 30.700 & \multirow{3}{*}{ Absent } & 20.466 & \multirow{3}{*}{ Absent } & 24.233 & \multirow{3}{*}{ Absent } & 30.866 & \multirow{3}{*}{ Absent } \\
\hline & Length $(\mu \mathrm{m})$ & 0.333 & & 0.334 & & 0.360 & & 0.390 & \\
\hline & Width $(\mu \mathrm{m})$ & 0.352 & & 0.500 & & 0.391 & & 0.420 & \\
\hline
\end{tabular}

Table 3. Ultrastructure of palisade mesophyll cells of leaves of common clementine scion grafted onto different rootstocks. Ultrastructure characters of palisade mesophyll cells of leaves of common clementine scion grafted onto diploid (C/CC2x) and doubled diploid (C/CC4x) Carrizo citrange and diploid (C/CM2x) and doubled diploid (C/CM4x) Citrumelo 4475 rootstocks grown in nutrient reference solution (100\%) and without nutrient solution $(0 \%)$ for 210 days. Values are means ( \pm standard error) of independent measurements on five different cells section $(n=5)$ for length, width and thickness of cells and for number of chloroplasts, starches, plastoglobuli and mitochondria and of 30 independent measurements on different cells section $(n=30)$ for length and width of chloroplasts, starches, plastoglobuli, mitochondria, grana, number of grana per cells section and number of thylakoids per granum. The heatmap shows the differences between the four scion/rootstocks combinations and treatments for each characteristic. Values are associated with color ranging from yellow (low) to dark green (high).

Better tolerance to nutrient stress in $2 x$ common clementine scion grafted onto the $4 \mathrm{x}$ citrumelo 4475 rootstock may be explained by a better antioxidant system.

Nutrient deprivation led to a modification of oxidative metabolism ${ }^{39,43,63}$. Tolerance differences between scion/ rootstock combinations may be related to differences in ROS production and/or antioxidant system efficiency. The enzymatic antioxidant system response differs according to plant species and the deficient minerals ${ }^{63-67}$. Enzymatic antioxidant systems in 2x common clementine leaves differed depending on the genotypes and/or the ploidy level of the rootstock (Fig. 6).

However, it was greater in C/CM4x than in the other scion/rootstock combinations.

Despite the decline in SOD activity and the increased or similar values in APX activity in all scion/rootstock combinations (Fig. 6A,C), CAT activity increased only in C/CM4x under nutrient deficiency (Fig. 6B). Concurrent CAT and APX activity is important for the elimination of $\mathrm{H}_{2} \mathrm{O}_{2}{ }^{68-70}$. In C/CM2x, C/CC2x and C/CC4x, the low $\mathrm{H}_{2} \mathrm{O}_{2}$ and high MDA contents were due to increased $\mathrm{OH}$ formation (Fig. 6D,E). This $\mathrm{OH}$ is either directly formed by the addition of electrons to the $\mathrm{O}_{2}{ }^{--}$not transformed into $\mathrm{H}_{2} \mathrm{O}_{2}$ by SOD and/or by the transformation of $\mathrm{H}_{2} \mathrm{O}_{2}$ via Fenton or Haber-Weiss reactions when the APX activity is insufficient to compensate for the low 


\begin{tabular}{|c|c|c|c|c|c|c|c|c|c|}
\hline & & \multirow{2}{*}{\multicolumn{2}{|c|}{$\operatorname{C} / \operatorname{CC} 2 x$}} & \multicolumn{2}{|c|}{$\mathrm{C} / \mathrm{CC} 4 \mathrm{x}$} & \multicolumn{2}{|c|}{ C/CM2x } & \multicolumn{2}{|c|}{$\mathrm{C} / \mathrm{CM} 4 \mathrm{x}$} \\
\hline \multirow{2}{*}{\multicolumn{2}{|c|}{ Characters }} & & & \multicolumn{4}{|c|}{ Spongy mesophyll cells } & & \\
\hline & & $100 \%$ & $0 \%$ & $100 \%$ & $0 \%$ & $100 \%$ & $0 \%$ & $100 \%$ & $0 \%$ \\
\hline \multirow{3}{*}{ Cells } & Length $(\mu \mathrm{m})$ & 24.430 & 26.335 & 18.986 & 33.430 & 18.210 & 17.650 & 23.004 & 25.330 \\
\hline & Width $(\mu \mathrm{m})$ & 20.780 & 16.942 & 15.472 & 24.126 & 14.028 & 13.342 & 17.746 & 16.770 \\
\hline & Thickness $(\mu \mathrm{m})$ & 0.835 & 0.824 & 0.487 & 0.736 & 0.662 & 0.432 & 0.826 & 1.015 \\
\hline \multirow{3}{*}{ Chloroplasts } & Number & 5.800 & 3.600 & 3.800 & 2.200 & 4.666 & 3.200 & 5.000 & 5.400 \\
\hline & Length $(\mu \mathrm{m})$ & 6.753 & 4.092 & 5.631 & 3.708 & 6.374 & 4.843 & 6.952 & 6.204 \\
\hline & Width $(\mu \mathrm{m})$ & 3.501 & 1.818 & 3.360 & 1.665 & 3.845 & 3.104 & 3.206 & 2.786 \\
\hline \multirow{3}{*}{ Starches } & Number & 12.400 & 5.600 & 9.200 & 2.400 & 12.000 & 12.000 & 9.600 & 11.800 \\
\hline & Length $(\mu \mathrm{m})$ & 3.229 & 2.293 & 2.853 & 1.654 & 3.410 & 2.627 & 3.359 & 2.675 \\
\hline & Width $(\mu \mathrm{m})$ & 1.938 & 1.085 & 2.042 & 0.854 & 2.180 & 1.665 & 2.190 & 1.562 \\
\hline \multirow{3}{*}{ Plastoglobuli } & Number & 5.000 & 6.600 & 7.666 & 10.200 & 9.200 & 11.400 & 12.600 & 12.000 \\
\hline & Length $(\mu \mathrm{m})$ & 0.327 & 0.520 & 0.279 & 0.486 & 0.305 & 0.774 & 0.507 & 0.623 \\
\hline & Width $(\mu \mathrm{m})$ & 0.281 & 0.376 & 0.230 & 0.401 & 0.185 & 0.581 & 0.389 & 0.463 \\
\hline \multirow{3}{*}{ Mitochondria } & Number & 12.800 & 7.000 & 6.200 & 4.400 & 10.000 & 5.400 & 6.000 & 11.000 \\
\hline & Length $(\mu \mathrm{m})$ & 0.727 & 0.712 & 0.715 & 0.735 & 0.647 & 0.666 & 0.972 & 0.779 \\
\hline & Width $(\mu \mathrm{m})$ & 0.574 & 0.480 & 0.518 & 0.541 & 0.562 & 0.426 & 0.589 & 0.539 \\
\hline \multirow{3}{*}{ Grana } & Number of grana per cell & 13.100 & \multirow{3}{*}{ Absent } & 18.266 & \multirow{3}{*}{ Absent } & 14.966 & \multirow{3}{*}{ Absent } & 18.844 & \multirow{3}{*}{ Absent } \\
\hline & Length $(\mu \mathrm{m})$ & 0.501 & & 0.408 & & 0.464 & & 0.516 & \\
\hline & Width $(\mu \mathrm{m})$ & 0.692 & & 0.559 & & 0.396 & & 0.481 & \\
\hline
\end{tabular}

Table 4. Ultrastructure of spongy mesophyll cells of leaves of common clementine scion grafted onto different rootstocks. Ultrastructure characters of spongy mesophyll cells of leaves of common clementine scion grafted onto diploid (C/CC2x) and doubled diploid (C/CC4x) Carrizo citrange and diploid (C/CM2x) and doubled diploid (C/CM4x) Citrumelo 4475 rootstocks grown in nutrient reference solution (100\%) and without nutrient solution $(0 \%)$ for 210 days. Values are means ( \pm standard error) of independent measurements on five different cells section $(n=5)$ for length, width and thickness of cells and for number of chloroplasts, starches, plastoglobuli and mitochondria and of 30 independent measurements on different cells section $(n=30)$ for length and width of chloroplasts, starches, plastoglobuli, mitochondria, grana, number of grana per cells section and number of thylakoids per granum. The heatmap shows the differences between the four scion/rootstocks combinations and treatments for each characteristic. Values are associated with color ranging from yellow (low) to dark green (high).

CAT activity. Conversely, in C/CM4x, the synergistic activity of CAT and APX maintains the MDA content in C/ CM4x (Fig. 6B-D). As in their ungrafted counterparts, the increased enzymatic activity in response to nutrient deficiency may explain the reduced ultrastructural damage and decrease in photosynthetic activity in C/CM4x in comparison with the other scion/rootstock combinations. According to some study, the rootstock influences the scion performance by modifying their sources-sink relation ${ }^{16,71,72}$. A modification of gene expression in the roots of tetraploid Lime Rangpur (Citrus limonia, Osbeck) would regulate the source-sink relation between the rootstock and the scion improving the stress adaptation ${ }^{25}$.

Tetraploidy of the citrumelo 4475 would improve the performance of the enzyme-based antioxidant system and thus the photosynthetic activity in the $2 x$ common clementine scion, likely to change the regulation of the sources sink relation.

In conclusion, rootstock ploidy level had no effect on the structure of the $2 \mathrm{x}$ common clementine scion leaves (except stomata density in Carrizo citrange) whereas it induced modifications in the ultrastructural components. The impact of prolonged nutrient deficiency on the structure, ultrastructure, physiology and biochemistry of the $2 \mathrm{x}$ common clementine scion differed according to the variety and ploidy level of the rootstock. Among the four scion/rootstock combinations, 2x common clementine grafted with $4 x$ citrumelo 4475 rootstock (C/CM4x) 


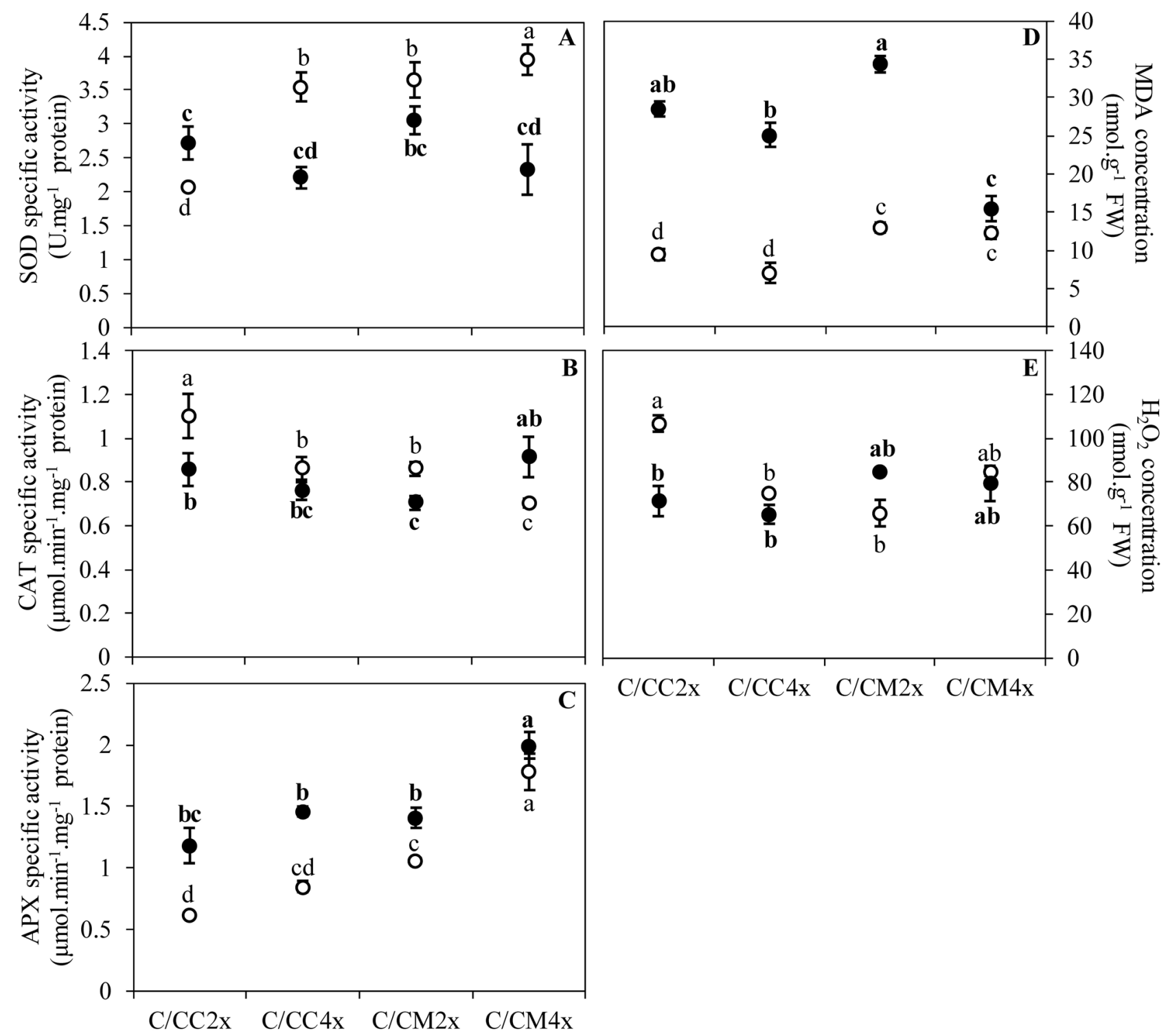

Figure 6. Effect of nutrient deficiency on antioxidant enzyme activities and contents in oxidative compounds in leaves of common clementine scion grafted onto different rootstocks. (A) Superoxide dismutase (SOD), (B) catalase (CAT) and (C) ascorbate peroxidase (APX) specific activities and (D) malondialdehyde (MDA) and (E) $\mathrm{H}_{2} \mathrm{O}_{2}$ contents in leaves of common clementine scion grafted onto diploid (C/CC2x) and doubled diploid $(\mathrm{C} / \mathrm{CC} 4 \mathrm{x})$ Carrizo citrange and diploid (C/CM2x) and doubled diploid (C/CM4x) Citrumelo 4475 rootstocks grown in nutrient reference solution (100\%) (white circles) and without nutrient solution ( $0 \%$ ) (black circles) for 210 days. Values are mean ( \pm standard error) of 3 independent measurements from 3 samples for each scion/rootstock combination, i.e. one per tree, obtained by pooling 8 fully-expanded leaves $(n=3)$. Ploidy and treatment effects were analyzed using ANOVA and Fisher LSD tests $(p<0.05)$. Distinct letters indicate significant differences between the four scion/rootstocks combinations and treatments.

was the most tolerant to nutrient deficiency as indicated by the limited changes in leaf cell structures and photosynthetic activity. The improved tolerance of $2 x$ common clementine grafted with $4 x$ citrumelo 4475 rootstock may be related to a better antioxidant system. Tolerance to nutrient deficiency can therefore be improved by rootstock polyploidy but remains dependent on the rootstock genotype. The next step of this study will be to test the impact of rootstock ploidy level on the quality and yield of clementine fruit under nutrient deficiency.

\section{Materials and methods}

Plant material and experimental design. The experiment was carried out on the AREFLEC experimental station located in San Giuliano, Corsica ( $41^{\circ} 47^{\prime} 27^{\prime \prime} \mathrm{N}$ and $09^{\circ} 23^{\prime} 40^{\prime \prime} \mathrm{E}$ ). $2 \mathrm{x}$ common clementine (Citrus clementina Hort. ex Tan; SRA 92) scion grafted onto one year seedlings of Carrizo citrange (Citrus sinensis L. Osb. $\times$ Poncirus trifoliata L. Raf.) and Citrumelo 4475 (Citrus paradisi L. Macf. $\times$ Poncirus trifoliata L. Raf.) $2 \mathrm{x}$ (C/CC2x and C/CM2x, respectively) and their $4 \times$ counterparts (C/CC4x and C/CM4x, respectively) were used 
as source materials. All, the citrus seeds have been provided by the INRAE-CIRAD of San Giuliano in Corsica (France) from the collection of the "CRB Citrus" biological resource center with the authorisation of Olivier Pailly, director of the INRAE Experimental Unit CITRUS of San Giuliano ${ }^{73}$. The INRAE-CIRAD center is recognized by the French Ministry of Agriculture, Food and Forestry. All the plant material mentioned comply with relevant institutional, national, and international guidelines and legislation. Subsequently, we cultivated the rootstocks and grafted them with the common clementine. The ploidy status of six seedlings for each combination was first checked by flow 10 cytometry (Partec I, Germany) ${ }^{74}$. Clonal propagation by nucellar embryogenesis was checked by genotyping using SSR markers ${ }^{75}$.

The four selected scion/rootstock combinations were then grown under identical conditions in vermiculite with fertigation and water $(1 \mathrm{~L} / \mathrm{h})$ for 3 years in a tunnel greenhouse. The stock solution used for irrigation included: $20-5-10 \mathrm{NPK}+2 \mathrm{MgO}$ fertilizer + trace elements according to the recommendations of the French department of agriculture. Seedlings were divided into two blocks: one with reference fertigation (control plants) and the other with irrigation water (without nutrient inputs). A total of three plants of each scion/rootstock combination were randomized by fertigation level $(n=3)$. The fertigation solutions were prepared and applied with a metering pump. Before starting the experiment, the vermiculite was washed for $48 \mathrm{~h}$ in order to eliminate any nutritional reserves in the pot.

According to a previous experiment ${ }^{29}$, leaf samples were collected and physiological measurements made from May to December 2018 at two different times (days): 0 (D0: control plant) and 210 (D210) days after the start of nutritional deprivation. Measurements were made and samples taken from homogeneous plants comprising four branches with fully-expanded leaves developed under stress and control conditions.

Mineral content was measured on a pool of eight fully expanded leaves for the three plants per combination and fertigation level $(n=3)$ between 10:00 and 11:00 am. Fresh leaves were placed in a forced air oven at 65 \pm 10 ${ }^{\circ} \mathrm{C}$ overnight and then transferred into a desiccator for cooling. The dehydrated leaves were then sent to the CIRAD "Analyses des eaux, sols et végétaux service unit" at Montpellier (France) for analysis of macro- and micro-nutrients.

Leaf P, K, Ca, Mg and Na contents were measured using an Agilent 720 simultaneous ICP-OES after double calcination with silica removal by adding hydrofluoric acid.

The leaf total $\mathrm{N}$ content was evaluated after combustion using a Leco TruMac $\mathrm{N}$ determinator.

Scanning electron microscopy (SEM). Scanning electron microscopy measurements were carried out on three leaf pieces per scion/rootstock combination and fertigation level (typically $\left.1 \mathrm{~cm}^{2}\right)(n=3)$ cut with a razor blade from mid-laminar areas at between 10:00 and 11:00 am. Leaves were then immediately fixed in cold $\left(4^{\circ} \mathrm{C}\right) 2.5 \%(\mathrm{v} / \mathrm{v})$ glutaraldehyde in $0.1 \mathrm{M}$ sodium cacodylate buffer at $\mathrm{pH} 7.2$, rinsed in a $0.1 \mathrm{M}$ cacodylate buffer at $\mathrm{pH} 7.2$, dehydrated through a graded ethanol series $(30 \%, 50 \%, 75 \%, 90 \%$ and $100 \%)$ and dried under $\mathrm{CO}_{2}$ in an Emitech K850 critical point dryer (Quorum Technologies Ltd, Ashford, U.K.) ${ }^{29}$. Specimens were mounted on aluminum stubs with carbon double-sided adhesive disks, coated with gold/palladium in a SC7640 sputter coater (Quorum Technologies Ltd, Newhaven, U.K.) and examined under a S-3400N scanning electron microscope (Hitachi High-Technologies Corporation, Tokyo, Japan) at an accelerating voltage of $5 \mathrm{kV}$.

Transmission electron microscopy (TEM). Transmission electron microscopy measurements were carried out on five leaf pieces per scion/rootstock combination and fertigation level (typically $\left.1 \mathrm{~mm}^{2}\right)(n=5)$ cut with a razor blade from mid-laminar areas at between 10:00 and 11:00 am. Leaves were immediately fixed in cold $\left(4^{\circ} \mathrm{C}\right) 2.5 \%$ glutaraldehyde in $0.1 \mathrm{M}$ sodium cacodylate buffer at $\mathrm{pH} 7.2$, rinsed in a $0.1 \mathrm{M}$ cacodylate buffer at $\mathrm{pH} 7.2$, post-fixed in cold $\left(4^{\circ} \mathrm{C}\right) 1 \%$ osmium tetroxide in the same buffer for $1 \mathrm{~h}$, dehydrated through a graded ethanol series (70\% and 100\%) and propylene oxide, embedded in Spurr, and polymerized at $60{ }^{\circ} \mathrm{C}$ for $24 \mathrm{~h}^{29}$. Ultra-thin sections (60-90 nm) were cut using a Power tome PC ultramicrotome (RMC Boeckeler, Tuscon, U.S.A.). Sections were placed on 200- and 300-mesh copper grids and stained with UranyLess (Delta Micoscopies, France) and lead citrate. They were then examined using a Hitachi H-7650 (Hitachi High-Technologies Corporation, Tokyo, Japan) at an accelerating voltage of $80 \mathrm{kV}$.

Measurements of gas exchange, chlorophyll content and chlorophyll a fluorescence. All measurements were made on three fully developed leaves for each of the three plants per combination and fertigation level $(n=9)$. A portable photosynthesis system (LI600) was used to measure the leaf net photosynthetic rate $\left(P_{\text {net }}\right)$, stomatal conductance $\left(g_{\mathrm{s}}\right)$ and transpiration rate $(\mathrm{E})$ at between 7:00 and 11:00 am. The carbon dioxide concentration $\left(\mathrm{CO}_{2}\right)$, airflow rate, light intensity and temperature of the leaf chamber were maintained at $380 \mu \mathrm{mol} \mathrm{mol}{ }^{-1}, 500 \mu \mathrm{mol} \mathrm{s}^{-1}, 1400 \mu \mathrm{mol} \mathrm{m}^{-2} \mathrm{~s}^{-1}$ and $25^{\circ} \mathrm{C}$, respectively.

The chlorophyll content was measured non-invasively with a Dualex Scientific + meter (FORCE-A, Paris). Values were obtained in Dualex units, convertibles to $\mathrm{g} \mathrm{cm}^{-2}$.

Chlorophyll $a$ fluorescence parameters were measured using an OS1p (Hansatech, Instruments Ltd) at between 9:00 and 11:00 am. Leaves were dark-acclimated for $30 \mathrm{~min}$ using special leaf clips. Chlorophyll a fluorescence was recorded after illumination with red actinic light $\left(650 \mathrm{~nm}, 3000 \mu \mathrm{mol}\right.$ photon $\left.\mathrm{m}^{-2} \mathrm{~s}^{-1}\right)$ for $1 \mathrm{~s}$ and this was used to calculate the maximum fluorescence $\left[F_{\mathrm{v}} / F_{\mathrm{m}}=\left(F_{\mathrm{m}}-F_{\mathrm{o}}\right) / \mathrm{F}_{\mathrm{m}}\right]^{76}$. Leaves were exposed to an actinic light to evaluate the current fluorescence yield $\left(F_{\mathrm{s}}\right)$ and the actual light-adapted fluorescence $\left(F_{\mathrm{m}}{ }^{\prime}\right)$. Formulas were applied to this data in order to determine the effective quantum yield of PSII Y (II $\left.)=\left(F_{\mathrm{m}}{ }^{\prime}-F_{s}\right) / F_{\mathrm{m}}{ }^{\prime}\right]$, the $\left.\mathrm{Y}(\mathrm{NO})=F_{\mathrm{s}} / F_{\mathrm{m}}\right]$, the non-photochemical quenching coefficient $\left[\mathrm{Y}(\mathrm{NPQ})=\left(F_{\mathrm{s}} / F_{\mathrm{m}}{ }^{\prime}\right)-\mathrm{Y}(\mathrm{NO})\right]^{77,78}$, and the electron transport rate through PSII $[\mathrm{ETR}(\mathrm{II})=\mathrm{Y}(\mathrm{II}) \times \mathrm{PAR} \times 0.5 \times 0.84]^{79}$. The ETR $/ P_{\text {net }}$ ratio was calculated to estimate the use of electrons in other processes unrelated to the photosynthetic $\mathrm{CO}_{2}$ assimilation rate. 
Determination of oxidative stress and antioxidant levels. Biochemical analyses were performed on three samples for each scion/rootstock combination, i.e. one per tree, obtained by pooling eight fully-expanded leaves $(n=3)$ collected between 10:00 and 11:00 am and immediately immersed in liquid nitrogen and stored at $-80^{\circ} \mathrm{C}$. Immediately prior to biochemical analysis, each leaf was ground to a fine powder in liquid nitrogen.

Malondialdehyde (MDA) and antioxidant enzyme activities (SOD, CAT, and APX) were assayed as defined by Santini et al. ${ }^{80}$.

Hydrogen peroxide $\left(\mathrm{H}_{2} \mathrm{O}_{2}\right)$ was assayed using the PeroxiDetect kit (Sigma-Aldrich). This technique is based on the oxidation of ferrous $\left(\mathrm{Fe}^{2+}\right)$ to ferric ions $\left(\mathrm{Fe}^{3+}\right)$ by hydroperoxides which react with xylenol orange ("3,3'-bis[N,N-bis(carboxymethyl)aminomethyl] o-cresolsulfonephthalein, sodium salt") to form a blue complex visible at $560 \mathrm{~nm}$.

Proline content was measured as described by Oustric et al. ${ }^{81}$.

A V-630 spectrophotometer was used for all measurements (Jasco Inc., Tokyo, Japan).

Statistical analyses. All statistical measurements were performed with R statistical software (v.2.12.1) (http://www.R-project.org) and the Rcmdr package. The qualitative factors studied were sampling date (D0 and D210 after nutrient deficiency), the clementine scion grafted onto rootstocks subjected to nutrient stress (C/CC and $\mathrm{C} / \mathrm{CM}$ ) and the ploidy level of nutrient stressed rootstocks (C/CC2x, C/CC4x, C/CM2x and C/CM4x). The influence of these three factors was analyzed using a two-way ANOVA followed by LSD test at $p<0.05$ for photosynthetic parameters (Fig. 2), microscopic parameters (Supplementary Tables S1-S3) and antioxidant enzyme activities and contents in oxidative compounds (Fig. 6).

To investigate microscopic profile of the clementine scion overs, the sampling date, the nutrient stressed rootstock genotypes and their ploidy level, the microscopic data were represented as a heatmap to facilitate visualization (Tables 2, 3, 4). Both heatmaps and hierarchical cluster analysis were generated by Heatmap.2 function of the gplot package 3.0.1 for Rstudio (v.1.3.1093) (https://rstudio.com).

Received: 27 November 2020; Accepted: 9 April 2021

Published online: 26 April 2021

\section{References}

1. Marschner, H. Mineral Nutrition of Higher Plants 2nd edn. (Academic Press, 1995).

2. Grusak, M. A. Plant Macro-and Micronutrient Minerals (eLS, 2001).

3. Lal, R. Enhancing crop yields in the developing countries through restoration of the soil organic carbon pool in agricultural lands. Land Degrad. Dev. 17, 197-209 (2006).

4. Ericsson, T. Growth and shoot: Root ratio of seedlings in relation to nutrient availability. In Nutrient Uptake and Cycling in Forest Ecosystems (eds Nilsson, L. O. et al.) 205-214 (Springer, 1995).

5. Kalaji, H. M. et al. Identification of nutrient deficiency in maize and tomato plants by in vivo chlorophyll a fluorescence measurements. Plant Physiol. Biochem. 81, 16-25 (2014).

6. Du, Q. et al. Effects of potassium deficiency on photosynthesis, chloroplast ultrastructure, ROS, and antioxidant activities in maize (Zea mays L.). J. Integr. Agric. 18, 395-406 (2019).

7. Mittler, R. Oxidative stress, antioxidants and stress tolerance. Trends Plant Sci. 7, 405-410 (2002).

8. Mittler, R., Vanderauwera, S., Gollery, M. \& Van Breusegem, F. Reactive oxygen gene network of plants. Trends Plant Sci. 9, 490-498 (2004).

9. Apel, K. \& Hirt, H. Reactive oxygen species: Metabolism, oxidative stress, and signal transduction. Annu. Rev. Plant Biol. 55, 373-399 (2004).

10. Kucukyumuk, Z. \& Erdal, I. Rootstock and cultivar effect on mineral nutrition, seasonal nutrient variation and correlations among leaf, flower and fruit nutrient concentrations in apple trees. Bulg. J. Agric. Sci. 17, 633-641 (2011).

11. Lee, J.-M. et al. Current status of vegetable grafting: Diffusion, grafting techniques, automation. Sci. Hortic. 127, 93-105 (2010).

12. Wang, Q., Men, L., Gao, L. \& Tian, Y. Effect of grafting and gypsum application on cucumber (Cucumis sativus L.) growth under saline water irrigation. Agric. Water Manage. 188, 79-90 (2017).

13. Benjamin, G., Tietel, Z. \& Porat, R. Effects of rootstock/scion combinations on the flavor of citrus fruit. J. Agric. Food Chem. 61, 11286-11294 (2013).

14. Saini, M. K., Capalash, N., Kaur, C. \& Singh, S. P. Comprehensive metabolic profiling to decipher the influence of rootstocks on fruit juice metabolome of Kinnow (C. nobilis $\times$ C. deliciosa). Sci. Hortic. 257, 108673 (2019).

15. Lu, Z.-J. et al. The effects of inarching Citrus reticulata Blanco var. tangerine on the tree vigor, nutrient status and fruit quality of Citrus sinensis Osbeck 'Newhall'trees that have Poncirus trifoliata (L.) Raf. as rootstocks. Sci. Hortic. 256, 108600 (2019).

16. Martínez-Ballesta, M. C., Alcaraz-López, C., Muries, B., Mota-Cadenas, C. \& Carvajal, M. Physiological aspects of rootstock-scion interactions. Sci. Hortic. 127, 112-118 (2010).

17. Schwarz, D., Rouphael, Y., Colla, G. \& Venema, J. H. Grafting as a tool to improve tolerance of vegetables to abiotic stresses: Thermal stress, water stress and organic pollutants. Sci. Hortic. 127, 162-171 (2010).

18. Taylor, B. K. \& Dimsey, R. T. Rootstock and scion effects on the leaf nutrient composition of citrus trees. Aust. J. Exp. Agric. 33, 363-371 (1993).

19. Cameron, J. Genetics, Breeding and Nucellar Embryony 325-370 (The Citrus Industry, Berlin, 1968).

20. Ruiz, M., Oustric, J., Santini, J. \& Morillon, R. Synthetic polyploidy in grafted crops. Front. Plant Sci. 11, 329 (2020).

21. Doyle, J. J. \& Coate, J. E. Polyploidy, the nucleotype, and novelty: The impact of genome doubling on the biology of the cell. Int. J. Plant Sci. 180, 1-52 (2018).

22. Jacquemond, C. \& Rocca-Serra, D. Citrus rootstocks selection in Corsica for 25 years. Proc. Int. Soc. Citricult. 1, 246-251 (1992).

23. Hussain, S., Curk, F., Ollitrault, P., Morillon, R. \& Luro, F. Facultative apomixis and chromosome doubling are sources of heterogeneity in citrus rootstock trials: Impact on clementine production and breeding selection. Sci. Hortic. 130, 815-819 (2011).

24. Hussain, S. et al. Autotetraploid trifoliate orange (Poncirus trifoliata) rootstocks do not impact clementine quality but reduce fruit yields and highly modify rootstock/scion physiology. Sci. Hortic. 134, 100-107 (2012).

25. Allario, T. et al. Tetraploid Rangpur lime rootstock increases drought tolerance via enhanced constitutive root abscisic acid production. Plant Cell Environ. 36, 856 (2013).

26. Oustric, J. et al. Tetraploid Carrizo citrange rootstock (Citrus sinensis Osb. $\times$ Poncirus trifoliata L. Raf.) enhances natural chilling stress tolerance of common clementine (Citrus clementina Hort. Ex Tan). J. Plant Physiol. 214, 108-115 (2017). 
27. Balal, R. M. et al. Kinnow mandarin plants grafted on tetraploid rootstocks are more tolerant to Cr-toxicity than those grafted on its diploids one. Environ. Exp. Bot. 140, 8-18 (2017).

28. Jacquemond, C., Curk, F. \& Heuzet, M. Les Clémentiniers et Autres Petits Agrumes (Editions Quae, 2013).

29. Oustric, J. et al. Tetraploid citrus seedlings subjected to long-term nutrient deficiency are less affected at the ultrastructural, physiological and biochemical levels than diploid ones. Plant Physiol. Biochem. 135, 372-384 (2019).

30. Evans, J. R. \& Terashima, I. Photosynthetic characteristics of spinach leaves grown with different nitrogen treatments. Plant Cell Physiol. 29, 157-165 (1988).

31. Bondada, B. R. \& Syvertsen, J. P. Leaf chlorophyll, net gas exchange and chloroplast ultrastructure in citrus leaves of different nitrogen status. Tree Physiol. 23, 553-559 (2003).

32. Tucker, M. Primary nutrients and plant growth. Essent. Plant Nutr. 126, (2004).

33. Padoan, D., Mossad, A., Chiancone, B., Germana, M. A. \& Khan, P. S. S. V. Ploidy levels in Citrus clementine affects leaf morphology, stomatal density and water content. Theor. Exp. Plant Physiol. 25, 283-290 (2013).

34. Jaskani, M. J., Khan, M. M. \& Khan, I. A. Growth, morphology and fruit comparison of diploid and tetraploid Kinnow mandarin. Pak. J. Agric. Sci. 39, 126-128 (2002).

35. Büssis, D., von Groll, U., Fisahn, J. \& Altmann, T. Stomatal aperture can compensate altered stomatal density in Arabidopsis thaliana at growth light conditions. Funct. Plant Biol. 33, 1037-1043 (2006).

36. Sack, F. D. \& Paolillo, D. J. Jr. Protoplasmic changes during stomatal development in Funaria. Can. J. Bot. 61, 2515-2526 (1983).

37. Horrer, D. et al. Blue light induces a distinct starch degradation pathway in guard cells for stomatal opening. Curr. Biol. 26, 362-370 (2016)

38. Okie, J. G., Smith, V. H. \& Martin-Cereceda, M. Major evolutionary transitions of life, metabolic scaling and the number and size of mitochondria and chloroplasts. Proc. R. Soc. B Biol. Sci. 283, 20160611 (2016).

39. Tewari, R. K., Kumar, P. \& Sharma, P. N. Oxidative stress and antioxidant responses in young leaves of mulberry plants grown under nitrogen, phosphorus or potassium deficiency. J. Integr. Plant Biol. 49, 313-322 (2007).

40. Sárvári, É. Effect of Cd on the iron re-supply-induced formation of chlorophyll-protein complexes in cucumber. Acta Biol. Szeged. 52, 183-186 (2008).

41. Shimshi, D. Leaf chlorosis and stomatal aperture. New Phytol. 66, 455-461 (1967).

42. de Cianzio, S. R., de Fehr, W. \& Anderson, I. C. Genotypic evaluation for iron deficiency chlorosis in soybeans by visual scores and chlorophyll concentration 1. Crop Sci. 19, 644-646 (1979).

43. Cakmak, S., Gülüt, K. Y., Marschner, H. \& Graham, R. D. Efect of zinc and iron deficiency on phytoslderophore release in wheat genotypes differing in zinc efficiency. J. Plant Nutr. 17, 1-17 (1994).

44. Wu, X., Lu, X., Riaz, M., Yan, L. \& Jiang, C. Boron toxicity induced specific changes of cell ultrastructure and architecture of components in leaf center and tip of trifoliate orange [Poncirus trifoliata (L.) Raf.]. J. Environ. Manage. 246, 426-433 (2019).

45. Flexas, J. et al. Diffusional conductances to $\mathrm{CO} 2$ as a target for increasing photosynthesis and photosynthetic water-use efficiency. Photosynth. Res. 117, 45-59 (2013).

46. Epron, D. \& Dreyer, E. Stomatal and non stomatal limitation of photosynthesis by leaf water deficits in three oak species: A comparison of gas exchange and chlorophyll a fluorescence data. Ann. Sci. For. 47, 435-450 (1990).

47. Flexas, J. \& Medrano, H. Drought-inhibition of photosynthesis in C3 plants: Stomatal and non-stomatal limitations revisited. Ann. Bot. 89, 183-189 (2002).

48. Baker, N. R. Chlorophyll fluorescence: A probe of photosynthesis in vivo. Annu. Rev. Plant Biol. 59, 89-113 (2008).

49. Papadakis, I. E. et al. $\mathrm{Mn}$-induced changes in leaf structure and chloroplast ultrastructure of Citrus volkameriana (L.) plants. J. Plant Physiol. 164, 100-103 (2007).

50. Zechmann, B. Subcellular roles of glutathione in mediating plant defense during biotic stress. Plants 9, 1067 (2020).

51. Thomas, R. Q., Zaehle, S., Templer, P. H. \& Goodale, C. L. Global patterns of nitrogen limitation: Confronting two global biogeochemical models with observations. Glob. Change Biol. 19, 2986-2998 (2013).

52. Pottier, M., Masclaux Daubresse, C., Yoshimoto, K. \& Thomine, S. Autophagy as a possible mechanism for micronutrient remobilization from leaves to seeds. Front. Plant Sci. 5, 11 (2014).

53. Kirchhoff, H. Diffusion of molecules and macromolecules in thylakoid membranes. Biochim. Biophys. Acta BBA-Bioenergy 1837, 495-502 (2014).

54. Lu, C. \& Zhang, J. Photosynthetic $\mathrm{CO} 2$ assimilation, chlorophyll fluorescence and photoinhibition as affected by nitrogen deficiency in maize plants. Plant Sci. 151, 135-143 (2000).

55. Zhao, L.-S. et al. Nitrogen starvation impacts the photosynthetic performance of Porphyridium cruentum as revealed by chlorophyll a fluorescence. Sci. Rep. 7, 1-11 (2017).

56. Eymery, F. \& Rey, P. Immunocytolocalization of CDSP 32 and CDSP 34, two chloroplastic drought-induced stress proteins in Solanum tuberosum plants. Plant Physiol. Biochem. 37, 305-312 (1999).

57. Zhang, M.-P. et al. Changes in chloroplast ultrastructure, fatty acid components of thylakoid membrane and chlorophyll a fluorescence transient in flag leaves of a super-high-yield hybrid rice and its parents during the reproductive stage. J. Plant Physiol. $167,277-285$ (2010).

58. Fatihi, A. et al. A dedicated type II NADPH dehydrogenase performs the penultimate step in the biosynthesis of vitamin K1 in Synechocystis and Arabidopsis. Plant Cell 27, 1730-1741 (2015).

59. Spiller, S. \& Terry, N. Limiting factors in photosynthesis. II. Iron stress diminishes photochemical capacity by reducing the number of photosynthetic units. Plant Physiol. 65, 121-125 (1980).

60. Besagni, C. \& Kessler, F. A mechanism implicating plastoglobules in thylakoid disassembly during senescence and nitrogen starvation. Planta 237, 463-470 (2013).

61. Lichtenthaler, H. K. Plastoglobuli and fine structure of plastids. Endeavour 27, 144 (1968).

62. Kutík, J., Cincerova, A. \& Dvorak, M. Chloroplast ultrastructural development during the ontogeny of the second leaf of wheat under nitrogen deficiency. Photosynth. Praha 28, 447-453 (1993).

63. Huang, S. et al. Improving nutritional quality of maize proteins by expressing sense and antisense zein genes. J. Agric. Food Chem. 52, 1958-1964 (2004).

64. Del Rio, L. A., Gomez, M., Yanez, J., Leal, A. \& Gorge, J. L. Iron deficiency in pea plants effect on catalase, peroxidase, chlorophyll and proteins of leaves. Plant Soil 49, 343-353 (1978).

65. Tewari, R. K. Role of mineral nutrient elements in Mulberry (Morus alba L.) Plants with particular reference to oxidative metabolism. (Ph. D thesis, University of Lucknow, India, 2004).

66. Gorbe, E. \& Calatayud, Á. Optimization of nutrition in soilless systems: A review. In Advances in Botanical Research Vol. 53 (eds Kader, J.-C. \& Delseny, M.) 193-245 (Academic Press, 2010).

67. Valipour, M., Baninasab, B., Khoshgoftarmanesh, A. H. \& Gholami, M. Oxidative stress and antioxidant responses to direct and bicarbonate-induced iron deficiency in two quince rootstocks. Sci. Hortic. 261, 108933 (2020).

68. Hertwig, B., Streb, P. \& Feierabend, J. Light dependence of catalase synthesis and degradation in leaves and the influence of interfering stress conditions. Plant Physiol. 100, 1547-1553 (1992).

69. Wang, J., Zhang, H. \& Allen, R. D. Overexpression of an arabidopsis peroxisomal ascorbate peroxidase gene in tobacco increases protection against oxidative stress. Plant Cell Physiol. 40, 725-732 (1999).

70. Shigeoka, S. et al. Regulation and function of ascorbate peroxidase isoenzymes. J. Exp. Bot. 53, 1305-1319 (2002). 
71. Gonçalves, L. P. et al. Rootstock-induced physiological and biochemical mechanisms of drought tolerance in sweet orange. Acta Physiol. Plant. 38, 1-12 (2016).

72. Zombardo, A. et al. Transcriptomic and biochemical investigations support the role of rootstock-scion interaction in grapevine berry quality. BMC Genomics 21, 1-20 (2020).

73. Fiorentino, G. \& Zech-Matterne, V. AGRUMED: Archaeology and History of Citrus Fruit in the Mediterranean: Acclimatization, Diversifications, Uses (Publications du Centre Jean Bérard, 2017).

74. Froelicher, Y. et al. Induced parthenogenesis in mandarin for haploid production: Induction procedures and genetic analysis of plantlets. Plant Cell Rep. 26, 937-944 (2007).

75. Vieira, D. D. S. S. et al. Polyploidization alters constitutive content of volatile organic compounds (VOC) and improves membrane stability under water deficit in Volkamer lemon (Citrus limonia Osb.) leaves. Environ. Exp. Bot. 126, 1-9 (2016).

76. Maxwell, K. \& Johnson, G. N. Chlorophyll fluorescence-A practical guide. J. Exp. Bot. 51, 659-668 (2000).

77. Kramer, D. M., Johnson, G., Kiirats, O. \& Edwards, G. E. New fluorescence parameters for the determination of Q A redox state and excitation energy fluxes. Photosynth. Res. 79, 209 (2004).

78. Klughammer, C. \& Schreiber, U. Complementary PS II quantum yields calculated from simple fluorescence parameters measured by PAM fluorometry and the saturation pulse method. PAM Appl. Notes 1, 201-247 (2008).

79. Bilger, W., Schreiber, U. \& Bock, M. Determination of the quantum efficiency of photosystem II and of non-photochemical quenching of chlorophyll fluorescence in the field. Oecologia 102, 425-432 (1995).

80. Santini, J. et al. Comparison of photosynthesis and antioxidant performance of several Citrus and Fortunella species (Rutaceae) under natural chilling stress. Trees 27, 71-83 (2013).

81. Oustric, J. et al. Nutrient deficiency tolerance in citrus is dependent on genotype or ploidy level. Front. Plant Sci. 10, 127 (2019).

\section{Acknowledgements}

This work was funded by the "Collectivité de Corse" as part of the "Innov'agrumes" research project (FEDER). We thank Jean-Claude Ribaut for hosting this study at the AREFLEC experimental station, and Gilles Paolacci and Paul Martin for installing and monitoring the fertigation system in the greenhouse.

\section{Author contributions}

O.J. collected data, did the statistical analysis, interpreted the results and drafted the manuscript. S.J. designed the study and drafted the manuscript. Q.Y. participated collect microscopic data. M.R., H.S., G.J. and B.L. designed the study and helped draft the manuscript.

\section{Competing interests}

The authors declare no competing interests.

\section{Additional information}

Supplementary Information The online version contains supplementary material available at https://doi.org/ 10.1038/s41598-021-88383-5.

Correspondence and requests for materials should be addressed to J.O.

Reprints and permissions information is available at www.nature.com/reprints.

Publisher's note Springer Nature remains neutral with regard to jurisdictional claims in published maps and institutional affiliations.

(c) (1) Open Access This article is licensed under a Creative Commons Attribution 4.0 International License, which permits use, sharing, adaptation, distribution and reproduction in any medium or format, as long as you give appropriate credit to the original author(s) and the source, provide a link to the Creative Commons licence, and indicate if changes were made. The images or other third party material in this article are included in the article's Creative Commons licence, unless indicated otherwise in a credit line to the material. If material is not included in the article's Creative Commons licence and your intended use is not permitted by statutory regulation or exceeds the permitted use, you will need to obtain permission directly from the copyright holder. To view a copy of this licence, visit http://creativecommons.org/licenses/by/4.0/.

(c) The Author(s) 2021 